\title{
THE PAN-AMERICAN SCIENTIFIC CONGRESS
}

The Second Pan-American Scientific Congress met in the City of Washington on December 27, 1915, and adjourned on January 8, 1916. It is to have a successor. The third of the scientific congresses will meet in the City of Lima on the 16th day of November, 1924. It was decided at the second congress that the third should meet at Lima, and it was anticipated that it would be within a period of five years from the date of adjournment. The continuance of the war, and the confusion of the international situation subsequent to and growing out of the war, have had their effects in the Americas. Finally, however, the obstacles standing in the way of a third congress have been overcome, and the official call has been issued by the Government of Peru. A circular signed by M. V. Villarán, as President, and José P. Bravo, as Secretary General of the Organization Committee, has been sent out in order to obtain at Lima, under the auspices of the congress, the presence of adequate representatives in all branches of science in the Western Continent. One has appropriately been received by the President of the American Society of International Law, requesting its cooperation and the appointment of official delegates to attend and to participate in the labors of the Third Pan American Scientific Congress.

In support of the statement that science in all its branches is to be represented, a brief quotation is made from the invitation to the American Society of International Law:

The Congress will comprise the nine Sections hereinbelow mentioned, the Presidents whereof have been appointed.

1.-Anthropology, History and related Sciences-President, Dr. Felipe de Osma, President of the Historical Institute of Peru.

2.-Physics, Mathematics and related Sciences-President, Rear Admiral M. Melitón Carbajal, President of the Geographical Society of Lima.

3.-Mining, Metallurgy, Economic Geology and Applied ChemistryPresident, Engineer José Balta, Professor of Economic Geology at the Lima School of Engineering.

4.--Engineering President, Engineer Darío Valdizán, Dean of Peruvian Engineers.

5.--Medicine and Sanitation-President, Dr. Guillermo Gastañeta, Dean of the Faculty of Medicine.

6.-Biology, Agriculture and related Sciences-President, Dr. Wenceslao F. Molina, Dean of the Faculty of Sciences.

7.-Private, Public and International Law-President, Dr. Mariano Ignacio Prado y Ugarteche, Dean of the Faculty of Jurisprudence.

8.-Economics and Sociology-President, Dr. José Matías Manzanilla, Dean of the Faculty of Politics and Economics.

9.-Education-President, Dr. Alejandro O. Deustua, Dean of the Faculty of Letters and Director of the National Library.

The congress opening on the 16th of November is expected to last a fortnight, and in this congress covering all branches of science, it is expected 
that the papers will cover at least its most important phases, and that they and their discussions will contribute in some measure to the advancement of science. It is of no small importance to bring the intellectual élite of the Americas together, who will discover their oneness notwithstanding differences of race, language and inherited traditions. "Scratch a Russian," they say, "and you will find a Tartar." Scratch an American of the North, of the Center and of the South, and you will find a human being. The great difficulty is to conserve the enthusiasm which is inevitably produced by these gatherings. The interval between them is considerable, and the influence of the second has spent itself long before the meeting of the third, just as the influence of the first had spent itself before the meeting of the second congress. The desideratum is that the connection between the congresses be preserved; that some machinery be devised which will keep in contact with the scientists during the intervals between the congresses, and that effect may be given, if only in part, to their recommendations, other than to have them fall still-born as has been the case with each of these international gatherings. Not the least important service of a third American Congress meeting at Lima would be the discovery of some means whereby the scientists of the Western Continent should keep in session, as it were, after their adjournment, and under direction continue their labors. The difficulty is great, but the greater the difficulty, the greater the need of meeting it.

It is to be hoped that many Americans of the North will find it possible to attend the congress, and take part in its proceedings. The meeting is to be held in the capital of Peru, and Peru has always made a special appeal to the Americans of the North. It is no discourtesy to the other American countries to say this, and any seeming discourtesy will be removed when the reason for it is given. That this should be so is a triumph of American literature. Many years ago, in 1847, a distinguished North American, one Prescott by name, published two volumes on the Conquest of Peru-a work speedily translated into Spanish, into French, and, indeed, into German and Dutch. The Americans of the North have been accustomed to read this masterpiece in their early youth, and the impression of the Incas of Peru, which they have received in their most impressionable period, remains with them all their lives, and Peru seems to them in no uncertain sense a land of dreams and of promise. The writer of this comment, if indeed it merits this title, has felt their charm, and he looks forward to the congress at Lima, which he hopes to attend in person.

If we only had a Prescott for every American Republic!

JAMES BROWN ScotT. 